\title{
PENGARUH PEMBERIAN AIR PERASAN JERUK NIPIS (CITRUS AURANTIFOLIA SWINGLE) TERHADAP KADAR KOLESTEROL PADA MENCIT HIPERKOLESTEROLEMIA
}

\author{
The Effect of Giving Water the Light of Lime (Citrus Aurantifolla Swingle) to Cholesterol \\ Levels in Hypercolesterolemia Mencit
}

\author{
Dewi Pangestuti \\ Bagian Farmakologi dan Terapi, Fakultas Kedokteran UISU Jln. STM No.77, \\ Suka Maju Medan, Sumatera Utara, Email : pangestuti241073@gmail.com
}

\begin{abstract}
Abstrak
Jeruk nipis (Citrus Aurantifolia) mengandung flavonoid utama dalam jeruk nipis, yaitu herperidin. Hesperidin dapat membantu mengurangi kadar kolesterol total dan memiliki sifat hiperkolesterolemia. Hiperkolesterolemia adalah faktor risiko independen utama penyakit jantung koroner (PJK). Penelitian ini bertujuan untuk mengetahui ada tidaknya pengaruh ekstrak air jeruk nipis secara oral dengan kadar kolesterol pada tikus hiperkolesterolemia. Isi penelitian eksperimental ini dirancang mengikuti desain kontrol acak dan post test only desain kelompok kontrol dengan menggunakan 24 tikus (Mus musculus) strain pria dewasa DD Webster dibagi menjadi 4 kelompok: kelompok kontrol (P0) yang Diberikan adlibitum, (P1) yang diberi hiperkolesterolemia 0,2 cc, (P3) yang diberi hiperkolesterolemia 0,2 cc dan ekstrak kapur air 0,3 cc dengan lambung sonde sehari sekali selama 15 hari. Pada hari ke-46 tikus dilakukan dislokasi leher. Hasil data dianalisis dengan uji One Way-Anova dan dilanjutkan dengan uji post-hoc. Hasil penelitian ini menunjukkan bahwa pemberian ekstrak air jeruk nipis 0,3 cc per tikus secara oral dapat menurunkan kadar kolesterol hiperkolesterolemia tikus dibandingkan pemberian ekstrak air jeruk nipis $0,1 \mathrm{cc}$ orraly per tikus.

Kata kunci: jeruk nipis, hesperidin, tingkat kolesterol, hiperkolesterolemia
\end{abstract}

\begin{abstract}
Lime (Citrus Aurantifolia) contains of main flavonoid in limes, that is herperidin. Hesperidin can help reducing total Cholesterol level and has the property of hypercholesterolemic. Hypercholesterolemia is the main factor independent risk factor of coronary heart disease (CHD). This study intend to determine whether or not the effect od water lime extract orally with cholesterol level in the hypercholesterolemia mice. This isi an experimental study designed following randomize control design and post test only control group design by using 24 mice (Mus musculus) adult male strain DD Webster divided into 4 groups: control group (P0) that Given adlibitum, (P1) that given hypercholesterolemia 0,2 cc, (P3) that given hypercholesterolemia $0,2 \mathrm{cc}$ and water lime extract $0,3 \mathrm{cc}$ by gastric sonde once a day for 15 days. In the day46 mice are done neck dislocation. Data result was analyzed by One Way- Anova test and continuous and continued with post-hoc test. Result of this study showed that giving of water lime extract $0,3 \mathrm{cc}$ orally per mice could reduced cholesterol level of mice hypercholesterolemia than giving water lime extract $0,1 \mathrm{cc}$ orraly per mice.
\end{abstract}

Keywords: lime, hesperidin, cholesterol level, hypercholesterolemia

\section{PENDAHULUAN}

Organisasi Kesehatan Dunia (WHO) melaporkan bahwa kadar kolesterol yang tinggi dalam darah menyumbang $56 \%$ dari kasus penyakit jantung koroner di seluruh dunia dan menyebabkan sekitar 4,4 juta kematian setiap tahunnya. Penyakit jantung koroner terutama disebabkan oleh aterosklerosis, yaitu penyempitan pembuluh darah koroner yang mengakibatkan insufisiensi aliran darah ke miokardium. Salah satu penyebab aterosklerosis adalah tingginya kadar kolesterol darah. Di Indonesia, sekitar 36 juta penduduk, atau sekitar $18 \%$ dari total penduduk Indonesia, menderita hiperkolesterolemia. (Stephanie et $a l, 2010$ ).

Citrus aurantifolia swingle merupakan nama ilmiah dari jeruk nipis. Sebutan "lime" dalam bahasa Inggris justru berasal dari Arab, yaitu limun dan Persia, yaitu limou. Tanaman jeruk nipis yang tumbuh di Indonesia berasal dari Birma Utara, Cina Selatan, India sebelah utara, tepatnya di 
Himalaya, serta Malaysia yang dibawa oleh orang Belanda. Selain vitamin C, kandungan flavonoid utama dalam jeruk nipis yaitu hesperidin dapat membantu menurunkan kadar kolesterol. Hesperidin dapat menghambat kerja enzim 3-hydroxy3methylglutaryl coenzim A-reductase sehingga dapat menekan sintesis kolesterol oleh hati dan dapat meningkatkan konsentrasi reseptor LDL. (Kurnia, 2014).

Hesperidin merupakan flavonoid spesifik pada buah jeruk yang memiliki sifat anti hiperkolesterolemik. Hesperidin paling banyak ditemukan pada jeruk yang masih muda dan berwarna hijau, konsentrasinya meningkat selama penyimpanan. Hesperidin memiliki efek signifikan dalam menurunkan kadar kolesterol, kadar kolesterol LDL dan meningkatkan kadar kolesterol HDL. Hesperidin berperan sebagai scavenger yang menangkap radikal bebas dan mencegah kerusakan akibat proses oksidasi (Haryanto \& Sayogo, 2013).

Menurut Aresta Wulan dalam penelitiannya menyatakan bahwa jeruk nipis berpengaruh dalam penurunan kolesterol tetap pada tikus sprague dawley (Aresta, 2014)

Penurunan kadar kolesterol plasma ditunjukkan pada penelitian Bok et al. pada tahun 1999 yang memberikan hesperidin pada 30 tikus jantan. Namun, pada penelitian Demonty et al. pada tahun 2010 yang memberikan hesperidin sintesis, tidak didapatkan efek hipokolesterolemik dari hesperidin (Haryanto \& Sayogo, 2013).

\section{Metodologi Penelitian}

Jenis penelitian ini dilakukan dengan menggunakan metode eksperimen yang didesain mengikuti rancangan randomize control design dan post test only control grup design untuk mengetahui pengaruh air perasan jeruk nipis terhadap kadar kolesterol pada mencit hiperkolesterolemia.

Penelitian dilaksanakan di Laboratorium FMIPA Biologi Universitas Sumatera Utara. Penelitian menggunakan mencit jantan (Dewasa) berusia 8 minggu dengan berat 25 40 gr. Mencit diperoleh dari Laboratorium FMIPA USU. Mencit penelitian di tempatkan pada kandang yang terbuat dari bahan plastik yang berukuran $30 \times 20 \times 10$ cm yang ditutup dengan kawat. Dasar kandang dilapisi dengan sekam padi dan diganti setiap tiga hasri sekali. Mencit dapat mengkonsumsi pakan standar (pellet komersial) 5-8 gr setiap hari dan minum 4-8 $\mathrm{ml}$ (air PAM) di berikan adlibitum setiap hari. Mencit di adaptasi selama 7 hari sebelum diberikan perlakuan. Setelah adaptasi kemudian bagi mencit dalam 4 kelompok secara acak atau random. Masing - masing 6 ekor mencit setiap kelompok P0, P1, P2, P3 setelah itu diberikan perlakuan.

Air perasan jeruk nipis, berasal dari buah jeruk nipis yang berkulit berwarna hijau yang dibeli dipasar tradisional sambas.

\section{Pembuatan Pakan diet tinggi lemak}

Makanan tinggi lemak yang akan digunakan pada penelitian ini adalah makanan berupa pellet ditambahkan kolesterol dari kuning telur $1,5 \%$, lemak kambing $10 \%$ dan minyak kelapa $1 \%$.

Cara mempersiapkan diet tinggi lemak yaitu dengan cara mengikuti tahaptahapan dibawah ini. Pertama-tama mempersiapkan minyak kelapa dengan cara mengambil daging kelapa tua sebanyak 1 buah dan diparut, diambil patinya kemudian pati tersebut dipanaskan diatas kuali hingga terpisah ampas dan minyak kelapa. Dan minyak kelapa disaring, diambil sebanyak 96 ml. Kedua, mempersiapkan kuning telur puyuh dengan memisahkan kuning telur dengan putihnya.

Bahan-bahan yang telah disiapkan dicampurkan dengan cara tuangkan minyak kelapa yang baru saja disiapkan dan ditambahkan air aquades, aduk hingga rata. Tambahan kuning telur puyuh kedalam wadah sedikit demi sedikit sambil diaduk hingga bahan-bahan tersebut diatas tercampur dengan rata. Kemudaian berikan ke mencit dengan menggunakan sonde lambung dengan dosis yang telah ditentukan.

\section{Bahan Jeruk Nipis}

Jeruk nipis digunakan adalah campuran air perasan jeruk nipis (Citrus Aurantifolia Swingle) beserta bulir-bulirnya $\pm 1.050 \mathrm{ml}$ jeruk nipis. Air perasan jeruk nipis yang digunakan adalah air perasan 
jeruk yang dibuat setiap hari selama intervensi.

\section{Prosedur Penelitian}

\section{Perlakuan Hewan Percobaan}

Jumlah total hewan coba yang dipergunakan dalam penelitian ini ada sebanyak 24 ekor. Penelitian ini terdiri dari atas 4 kelompok perlakuan, yaitu:

1. Kelompok I $(\mathrm{P} 0)=$ terdiri dari 6 ekor mencit jantan dewasa yang diberi pakan standar selama 45 hari.

2. Kelompok II $(\mathrm{P} 1)=$ terdiri dari 6 ekor mencit jantan dewasa yang diberi pakan standar selama 15 hari dan pakan hiperkolestrerol selama 30 hari

3. Kelompok III $(\mathrm{P} 2)=$ terdiri dari 6 ekor mencit jantan dewasa yang diberi pakan standar selama 15 hari dan pakan hiperkolestrerol 15 hari serta air perasan jeruk nipis $0,1 \mathrm{cc}+$ pakan hiperkolestrerol selama 15 hari

4. Kelompok IV $(\mathrm{P} 3)=$ terdiri dari 6 ekor mencit jantan dewasa yang diberi pakan standar selama 15 hari dan pakan hiperkolestrerol 15 hari serta air perasan jeruk nipis $0,3 \mathrm{cc}+$ pakan hiperkolestrerol selama 15 hari

Pemeriksaan kolesterol mencit pada hari ke-46 sampel darah yang telah diambilkan diletakan ke dalam tabung atau wadah steril dan dibawa ke Laboratorium
Kesehatan. Lalu ambil serum darah yang melalui proses centrifuge dengan memisahkan antara darah dengan serum darah dilakukan oleh peneliti. pemeriksaan menggunakan alat spektrofotometri atau kolometri. Mencit dikatakan turun kolesterol bila $\leq 200 \mathrm{mg} / \mathrm{dl}$.

\section{Analisa Data}

Data dipersentasikan dalam bentuk rata-rata \pm simpang baku (rata-rata $\pm \mathrm{SD}$ ). Dilakukan uji normalitas dan homoenitas data. Jika data berdistribusi normal dan homogen. Maka dilakukan uji ANOVA. Bila terdapat perbedaan dilakukan uji Post Hoc untuk melihat perbedaan antara kelompok control dan kelompok perlakukan. Jika distribusi data tidak normal atau tidak homogen, makan dilakukan transformasi data dan di uji lagi normalitas dan homogenitas data. Apabila masih tidak normal distribusinya atau tidak homogen maka di uji dengan uji Kruskal Wallis (ANOVA nonparametric) untuk melihat antara kelompok control dan kelompok perlakuan menggunakan Uji Mann-Whitney. Semua analisis data menggunakan SPSS 13.0, dalam penelitian ini, hanya perbedaan rata-rata pada $\leq 0,05$ yang dianggap bermakna (signifikan). 


\section{HASIL PENELITIAN DAN PEMBAHASAN}

\section{Hasil Penelitian}

Dari hasil penelitian yang dilakukan, maka diperoleh hasil perhitungan kadar kolesterol pada masing-masing kelompok ditunjukan pada gambar 1.

Gambar 1. Kadar Kolesterol Pada Mencit Hiperkolesterolemia.

\begin{tabular}{|c|c|c|c|c|c|c|}
\hline Perlakuan & Mencit 1 & Mencit 2 & Mencit 3 & Mencit 4 & Mencit 5 & Mencit 6 \\
\hline $\begin{array}{l}\text { P0 } \\
\text { (Kontrol) }\end{array}$ & $\begin{array}{l}167 \\
\mathrm{mg} / \mathrm{dl}\end{array}$ & $\begin{array}{l}170 \\
\mathrm{mg} / \mathrm{dl}\end{array}$ & $\begin{array}{l}167 \\
\mathrm{mg} / \mathrm{dl}\end{array}$ & $\begin{array}{l}172 \\
\mathrm{mg} / \mathrm{dl}\end{array}$ & $\begin{array}{l}178 \\
\mathrm{mg} / \mathrm{dl}\end{array}$ & $\begin{array}{l}165 \\
\mathrm{mg} / \mathrm{dl}\end{array}$ \\
\hline $\begin{array}{l}\text { P1 } \\
\text { (Pakan } \\
\text { Hiperkolesterol) }\end{array}$ & $\begin{array}{l}204 \\
\mathrm{mg} / \mathrm{dl}\end{array}$ & $\begin{array}{l}208 \\
\mathrm{mg} / \mathrm{dl}\end{array}$ & $\begin{array}{l}152 \\
\mathrm{mg} / \mathrm{dl}\end{array}$ & $\begin{array}{l}195 \\
\mathrm{mg} / \mathrm{dl}\end{array}$ & $\begin{array}{l}210 \\
\mathrm{mg} / \mathrm{dl}\end{array}$ & $\begin{array}{l}210 \\
\mathrm{mg} / \mathrm{dl}\end{array}$ \\
\hline $\begin{array}{l}\text { P2 } \\
\text { (Perlakuan } \\
0,1 \mathrm{cc} / \mathrm{BB} / \text { oral) }\end{array}$ & $\begin{array}{l}161 \\
\mathrm{mg} / \mathrm{dl}\end{array}$ & $\begin{array}{l}191 \\
\mathrm{mg} / \mathrm{dl}\end{array}$ & $\begin{array}{l}172 \\
\mathrm{mg} / \mathrm{dl}\end{array}$ & $\begin{array}{l}167 \\
\mathrm{mg} / \mathrm{dl}\end{array}$ & $\begin{array}{l}168 \\
\mathrm{mg} / \mathrm{dl}\end{array}$ & $\begin{array}{l}170 \\
\mathrm{mg} / \mathrm{dl}\end{array}$ \\
\hline $\begin{array}{l}\text { P3 } \\
\text { (Perlakuan } \\
0,3 \mathrm{cc} / \mathrm{BB} / \text { oral) }\end{array}$ & $\begin{array}{l}180 \\
\mathrm{mg} / \mathrm{dl}\end{array}$ & $\begin{array}{l}182 \\
\mathrm{mg} / \mathrm{dl}\end{array}$ & $\begin{array}{l}184 \\
\mathrm{mg} / \mathrm{dl}\end{array}$ & $\begin{array}{l}148 \\
\mathrm{mg} / \mathrm{dl}\end{array}$ & $\begin{array}{l}153 \\
\mathrm{mg} / \mathrm{dl}\end{array}$ & $\begin{array}{l}160 \\
\mathrm{mg} / \mathrm{dl}\end{array}$ \\
\hline
\end{tabular}

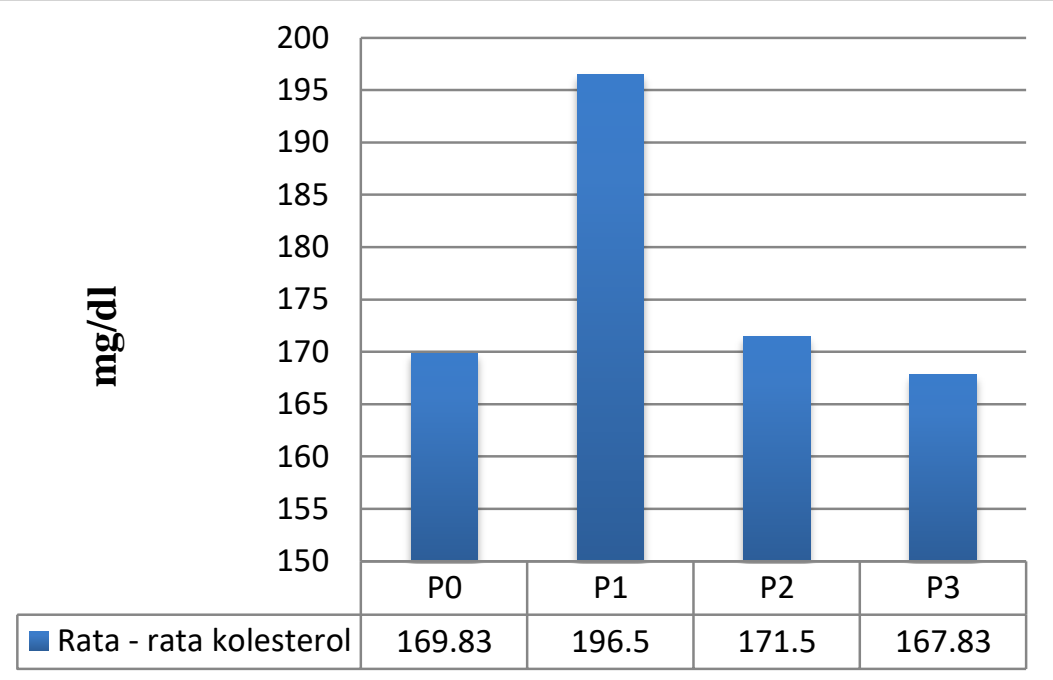

Gambar 2 Grafik Rata-Rata Kadar Kolesterol Pada Mencit Hiperkolesterolemia. Keterangan: $\mathrm{P} 0=$ Makan dan minum adlibitum, $\mathrm{P} 1=$ Pemberian Pakan Hiperkolesterolemia 0,2 cc, P2 = Pemberian Pakan Hiperkolesterolemia 0,2 cc dan Pemberian Air Perasan Jeruk Nipis 0,1 cc, P3 = Pemberian Pakan Hiperkolesterolemia 0,2 cc dan Pemberian Air Perasan Jeruk Nipis 0,3 cc.

Gambar 1 menunjukkan peningkatan kadar kolesterol pada perlakuan mencit yang diberikan pakan hiperkolesterol (P1). Kadar kolesterol tidak terjadi penurunan berarti pada perlakuan yang diberikan pakan hiperkolesterol dan diberikan air perasan jeruk nipis $0,1 \mathrm{cc}(\mathrm{P} 2)$. dan serta mencit yang diberikan hiperkolesterol dan diberikan air perasan jeruk nipis $0,3 \mathrm{cc}$ (P3) mengalami penurunan yang berarti.

Hasil analisis distribusi data dan homogenitas data adalah semua data pengukuran kadar kolesterol terdistribusi normal $(p \geq 0,05)$, sehingga tidak perlu dilakukan uji transformasi data dan dapat dilakukan uji ANOVA satu arah. Dari hasil uji ANOVA satu arah, ternyata ditemukan perbedaan bermakna kadar kolesterol antara masing-masing kelompok perlakuan penelitian. Oleh karena itu perlu dilakukan uji lanjut untuk melihat perbedaan masing-masing kelompok perlakuan dengan uji Post Hoc untuk melihat perbedaan antara 
kelompok kontrol dan kelompok perlakuan $(p \leq 0,05)$.

Berdasarkan hasil uji Post $\mathrm{Hoc}$ menunjukan perbedaan yang signifikan $(p \leq 0,05)$ antara kelompok kontrol dan kelompok perlakuan. Hasil nilai P0 dan P1 menunujukan hasil perbedaan bermakna. Sedangkan P1 dan P2 menunjukan hasil perbedaan tidak bermakna, dan P1 dan P3 menunjukan hasil perbedaan bermakna antara keduanya.

\section{Pembahasan}

Dari hasil penelitian ini ditemukan adanya peningkatan kadar kolesterol pada kelompok yang diberikan hiperkolesterol (P1) dibandingkan dengan kelompok kontrol (P0). Kelebihan lipid yang dikonsumsi setiap hari oleh mencit dapat meningkatkan kadar kolesterol pada mencit. Hal ini terjadi oleh karena pakan tinggi lemak yang dikonsumsi mencit diabsorbsi dengan baik. Pada jalur eksogen, menghantarkan lipid yang dikonsumsi ke jaringan tubuh dan hati. Trigliserida dan kolesterol yang dikonsumsi bergabung dengan apoprotein dalam mukosa usus untuk membentuk kilomikron. Kilomikron ini masuk ke dalam aliran darah melalui sistem limfatik, dan berikatan dengan endotel kapiler dalam otot dan jaringan adiposa. Didalam otot dan jaringan adiposa tersebut, trigliserida terhidrolisis oleh enzim lipoprotein lipase (LPL), menghasilkan asam lemak yang memasuki jaringan. Hati mengambil kilomikron renman residual. Kilomikron ini dipecah untuk membentuk kolesterol yang juga disentetis oleh hati (Aaroson \& Ward, 2010).

Pemberian pakan hiperkolesterol terhadap mencit berupa kuning telur puyuh dan minyak kelapa merupakan asupan lemak jenuh yang menyebabkan hiperkolesterolemia. (Haryanto \& Sayogo, 2013)

Dari hasil penelitian ini ditemukan adanya penurunan kadar kolesterol pada masing-masing kelompok yang diberikan perlakuan hiperkolesterol $+0,1$ cc jeruk nipis (P2) dengan kelompok perlakuan hiperkolesterol (P1). walaupun pada kelompok P2 tidak terjadi penurunan yang berarti. Pada perlakuan hiperkolesterol $+0,3 \mathrm{cc}$ jeruk nipis $(\mathrm{P} 3)$ dibandingkan dengan kelompok perlakuan hiperkolesterol (P1) didapat penurunan yang berarti. Penurunan ini terjadi karena adanya kandungan flavonoid utama dalam jeruk nipis yaitu hesperidin. (Kurnia, 2014). Hesperidin merupakan flavonoid spesifik pada buah jeruk nipis yang memilki sifat hipokolesterolemik. Hesperidine memiliki efek signifikan dalam menurunkan kadar kolesterol, kadar LDL dan meningkatkan kadar HDL. (Haryanto \& Sayogo, 2013)

Hesperidin dapat membantu menurunkan kadar kolesterol. Hesperidin dapat menghambat kerja enzim 3hydroxy-3methylglutaryl coenzim $A$ reductase sehingga dapat menekan sintesis kolesterol oleh hati dan dapat meningkatkan konsentrasi reseptor LDL. (Kurnia, 2014). Sesuai dengan penelitian Bok et al. pada tahun 1999 yang memberikan hesperidin pada 30 tikus jantan. (Haryanto \& Sayogo, 2013).

\section{Kesimpulan}

Dari hasil penelitian dapat disimpulkan:

1. Terdapat peningkatan yang bermakna kadar kolesterol antara perlakuan kelompok kontrol (P0) dengan yang diberikan pakan hiperkolesterol (P1).

2. Terdapat penurunan yang bermakna kadar kolesterol dengan perlakuan yang diberi pakan hiperkolesterol ditambah dengan $0,3 \mathrm{cc}$ jeruk nipis (P3).

\section{DAFTAR PUSTAKA}

Aaronson, P.I., Ward, Jeremy P.T., 2010. At a Glance Sistem Kardiovaskular. Ed. 3. Jakarta :Erlangga, Hal 78-79

Alwi, I., 2010. Stratifikasi Risiko Penyakit Jantung Koroner Pada Pasien Dislipidemia. Divisi Kardiologi Departemen Penyakit Dalam Fakultas Kedokteran 
Univesitas Indonesia Vol. 60, No.6. Jakarta. Hal 253

Arisman., 2011. Obesitas, diabetes mielitus \& dislipidemia: Konsep, teori, dan penganganan aplikatif. Jakarta: EGC. Hal 125

Gaw, Allan. et al., 2012. Biokimia Klinis : Teks Bergambar, Ed.4. Jakarta: EGC

Haryanto, A., Sayogo,S., 2013. Hiperkolesterolemia: Bagaimana Peran Hesperidine. Vol 40, No 1. Available from: http://www.kalbemed.com/Events. aspx

Kurnia, A., 2014. Khasiat Ajaib Jeruk Nipis - Dari A-Z untuk Kesehatan dan Kecantikan. Ed.1. Yogyakarta: Rapha Publishing
Stephanie, L. et al., 2010. Hubungan antara pengeluaran energi harian dengan kadar kolesterol total pada pasien usia minimal 30 tahun. Fakultas Kedokteran Universitas Tarumanagara. Vol.16, No.2, Hal 106.

Wulan, A., 2014. Pengaruh Pemberian Jus Pare (Momordica charantia L) dan Jeruk Nipis (Citrus aurantifolia) terhadap Kadar Kolesterol Total Tikus Sprague Dawley Hiperkolesterolemia. Universitas diponegoro, semarang 